\title{
Extraction And Characterization of Bioactive Peptides Derived from the Hydrolysates of Total Soluble Proteins of Pistachio Nuts [ Pistacia vera L.]
}

\author{
Nico G. Dumandan, Mark Rickard N. Angelia*, Ma. Desiree Belina-Aldemita, \\ Mary Ann O. Torio
}

Institute of Chemistry, College of Arts and Sciences, University of the Philippines Los Baños, College, Laguna 4031, Philippines

\begin{abstract}
This study explored the potential of pistachio nut (Pistacia vera L.) total soluble proteins to release bioactive peptides exhibiting angiotensin-converting enzyme (ACE) inhibition, antioxidative, and antibacterial activities. The total soluble proteins were extracted from the ground, defatted nut using $0.010 \mathrm{M}$ phosphate buffered saline, $\mathrm{pH}$ 6.8. The extracted proteins were hydrolyzed at different time intervals using trypsin and chymotrypsin. Hydrolysates of the total soluble proteins at $24 \mathrm{~h}$ digestion time exhibited the highest ACE-inhibition activity of $76.67 \pm 0.10 \%$ and $70.83 \pm 0.00 \%$ for chymotrypsin and trypsin digestion, respectively. The $24 \mathrm{~h}$ enzymatic hydrolysates were further fractionated in RP-HPLC using a C18 Vydac column. The C1 fraction from the 24 h chymotryptic hydrolysates and $\mathrm{T} 2$ from the $24 \mathrm{~h}$ tryptic hydrolysates exhibited the highest ACEinhibition activities with an $\mathrm{IC}_{50}$ value of $147.7 \pm 0.8$ and $148.7 \pm 0.6 \mu \mathrm{g} / \mathrm{mL}$, respectively. The $24 \mathrm{~h}$ chymotryptic and tryptic hydrolysates also exhibited a DPPH radical scavenging activity of $83.7 \pm 1.1 \%\left(\mathrm{EC}_{50}=356.5 \pm 1.0 \mu \mathrm{g} / \mathrm{mL}\right)$ and $80.4 \pm 0.2 \%$ $\left(\mathrm{EC}_{50}=402.7 \pm 1.1 \mu \mathrm{g} / \mathrm{mL}\right)$, respectively. The hydroxyl radical scavenging activities of the $24 \mathrm{~h}$ chymotryptic and tryptic hydrolysates were found to be $22.8 \pm 1.0$ and $16.6 \pm$ $3.7 \%$, respectively. However, the $24 \mathrm{~h}$ tryptic and chymotryptic hydrolysates did not exhibit any antibacterial activity against the gram-negative Escherichia coli and grampositive Staphylococcus aureus. Therefore, the total soluble proteins of pistachio nuts were found to contain peptides exhibiting ACE-inhibition and antioxidative activities upon hydrolysis with trypsin and chymotrypsin.
\end{abstract}

Keywords: Pistachio, antioxidative, antibacterial, angiotensin-converting, bioactive peptides

\section{INTRODUCTION}

Pistachio nuts (Pistacia vera L.) was ranked as one of the food products to contain the highest antioxidant potential due to its phenolic compounds (Halvorsen et al., 2006). Pistachio extracts have also been shown to exhibit anti-inflammatory, antinociceptive, and antimicrobial activities (Orhan et al., 2006; Ozcelik et al. 2005), as well as cardioprotective

\footnotetext{
*Author to whom correspondence should be addressed; email: mrnangelia@uplb.edu.ph
} 
and vasoprotective capacities (Rajaei et al., 2010).

Aside from the high phenolic content, pistachio nuts also contain high amounts of dietary proteins (Ros, 2010). En route to the human system, protein hydrolysates have been found to exhibit drug- or hormone-like activities that promote health. Proteins derived from plant food sources have more potent bioactivities such as antihypertensive, antioxidative, antimicrobial, opoid, modulatory, and other functionalities (Korhonen and Pihlanto, 2006).

In the Philippines, cardiovascular diseases and those caused by pathogens are among the leading causes of mortality (NSO, 2013). Thus, the utilization of natural food protein sources with health-promoting activities is significant. Hypertension or increased blood pressure is one of the most controllable risk factors associated with cardiovascular diseases and can be regulated through antihypertensive peptides with Angiotensin I-converting enzyme (ACE) inhibitory activity. ACE is an enzyme that converts angiotensin I to angiotensin II and is responsible for increase in blood pressure. Such ACE inhibiting peptides have the capability to minimize production of angiotensin II which in turn exhibits antihypertensive property (Natesh et al., 2003; Unger, 2002).

Cardiovascular diseases are also associated to chronic degenerative stresses invoked by many oxidative species such as reactive oxygen, nitrogen, and free radicals (Bowler and Crapo, 2002; Dhalla et al., 2000; Park et al., 2009). Antioxidative peptides contain a unique amino acid sequence that act as electron donors to free radicals resulting to a peptide radical that do not initiate or propagate further oxidation reactions (Elias et al., 2008).

The interest in antibacterial peptides as potential antibiotic pharmaceuticals is still in top priority due to their rapid and broadspectrum antibacterial property against antibiotic-resistant bacteria (Brogden and Brogden, 2011). These peptides perform their bioactivity by disrupting the cellular matrix of bacteria leading to cell death.
With these evidences that peptides have the effect of lowering blood pressure, reduce the risk of oxidative stress, and provide antagonistic role against bacterial strains, the exploitation of different plant proteins can be a means of screening for potential peptides that exhibit antihypertensive, antioxidative, and antibacterial activities. Hence, the main focus of this study is to screen for potential ACE-inhibiting, antioxidative, and antibacterial peptides present in pistachio nut (Pistacia vera L.) total soluble proteins.

\section{METHODOLOGY}

Sample Preparation. Fifty grams of decorticated pistachio nuts were ground to a fine paste using a mortar and pestle. The resulting meal was then defatted with $\mathrm{n}$ hexane in a 5:1 ratio of solvent volume to meal weight at $4{ }^{\circ} \mathrm{C}$ for $3 \mathrm{~h}$. The defatted meal was stored in freezer until use.

Extraction of Total Soluble Proteins. The total soluble proteins of pistachio nuts were extracted using $0.010 \mathrm{M}$ phosphate buffered saline $(\mathrm{pH}$ 6.8) in a 10:1 ratio of solvent volume to meal weight at $4^{\circ} \mathrm{C}$ for $3 \mathrm{~h}$. The resulting mixture was then filtered and centrifuged at $10,000 \times \mathrm{g}$ for $15 \mathrm{~min}$ at $4^{\circ} \mathrm{C}$ using an Allegra X-30R refrigerated centrifuge. The clarified crude extract was collected and stored at $4^{\circ} \mathrm{C}$ until use.

Protein Content Determination. The protein content of the sample was determined using Bradford (1976) with bovine serum albumin (BSA) as protein standard.

Enzymatic Hydrolysis of the Total Soluble Proteins. Four hundred microliters of the total soluble proteins $(1 \mathrm{mg} / \mathrm{mL})$ were digested separately with chymotrypsin and trypsin (1 $\mathrm{mg} / \mathrm{mL}$ ) using an enzyme to substrate ratio $(\mathrm{v} / \mathrm{v})$ of 1:8. Hydrolysis was performed at different time intervals $(0 \mathrm{~min}, 5 \mathrm{~min}, 15 \mathrm{~min}$, $30 \mathrm{~min}, 1 \mathrm{~h}, 5 \mathrm{~h}, 12 \mathrm{~h}$, and $24 \mathrm{~h}$ ) at $37^{\circ} \mathrm{C}$ and $\mathrm{pH}$ 7.4. Enzymatic activity was stopped by heating the digests at $100{ }^{\circ} \mathrm{C}$ for $10 \mathrm{~min}$. After heating, the mixture was immediately kept in ice. The progress of enzymatic hydrolysis was monitored using SDS-PAGE. 
Extraction of Angiotensin-Converting Enzyme (ACE) from Pig Lungs. Preparation of Acetone Lung Powder. The angiotensinconverting enzyme was extracted from the acetone pig lung powder according to the method of Folk et al. (1960) with slight modifications. The pig lungs were suspended in two volumes of acetone and then homogenized using a blender. The resulting mixture was filtered through cheesecloth and the residual solvent was evaporated from the tissue residue under the hood. The tissue residue was then resuspended in four volumes of diethyl ether, followed by homogenization using a blender. The solvent was then removed by filtration in cheesecloth while the residue was dried under the hood. The dried residue powder was used for ACE extraction.

ACE Extraction from Acetone Lung Powder. A modified method of Cushman and Cheung (1971) was used to extract ACE from acetone lung powder. The crude ACE was extracted from the acetone lung powder using $0.10 \mathrm{M}$ sodium borate buffer $(\mathrm{pH}$ 8.0) with $0.30 \mathrm{M}$ $\mathrm{NaCl}$ for $3 \mathrm{~h}$ at $4^{\circ} \mathrm{C}$. The mixture was then clarified at $10,000 \times \mathrm{g}$ for $40 \mathrm{~min}$ at $4^{\circ} \mathrm{C}$. The resulting clear, reddish supernatant was collected, labeled as the crude ACE extract and stored at $4^{\circ} \mathrm{C}$.

Reverse-Phase High Performance Liquid Chromatography (RP-HPLC). Fractionation of enzymatic hydrolysates was performed on Agilent Technologies 1200 Series HPLC system using a Vydac C18 column (4.6x250 $\mathrm{mm}, 5 \mu \mathrm{m}$ bead, $30 \mathrm{~mm}$ pore size). A $25 \mu \mathrm{L}$ sample was injected into the column and eluted at $25^{\circ} \mathrm{C}$ via a mobile phase using water and acetonitrile as solvents. Gradient elution was done starting from 2 to $60 \%$ water for $45 \mathrm{~min}$, 60 to $100 \%$ acetonitrile for $5 \mathrm{~min}$ and 98 to $2 \%$ acetonitrile for 2 min ending with $2 \%$ acetonitrile for $2 \mathrm{~min}$. The flow rate was set to $0.50 \mathrm{~mL} / \mathrm{min}$ and the peptide fractions were detected using a UV detector at $242 \mathrm{~nm}$. All samples were clarified using $0.45 \mu \mathrm{L}$ microfilter prior to analysis. Each fraction was collected manually and tested for ACE inhibitory activity. Fractions with high ACE inhibition were subjected to $\mathrm{IC}_{50}$ determination.
Characterization of Bioactive Peptides. Spectrophotometric Angiotensin Converting Ensyme (ACE) Inbibition Assay. The method of Cheung et al. (1980) with slight modifications was used to determine the ACE-inhibition activity of pistachio nut protein hydrolysates. A $250 \mu \mathrm{L}$ assay mixture containing $100 \mathrm{mM}$ phosphate buffer, $300 \mathrm{mM} \mathrm{NaCl}, 5 \mathrm{mM}$ hippuryl-L-histidine-L-leucine (HHL) and 50 $\mu \mathrm{L}$ protein hydrolysate was pre-incubated at $37^{\circ} \mathrm{C}$ for $5 \mathrm{~min}$. Fifty microliter ACE from pig lung was added to the assay mixture to initiate the reaction. For the control, $250 \mu \mathrm{L} 1 \mathrm{~N} \mathrm{HCl}$ was added first before adding the ACE. A blank solution was done by replacing the 50 $\mu \mathrm{L}$ protein hydrolysate with $100 \mathrm{mM}$ phosphate buffer. The assay mixtures were incubated at $37^{\circ} \mathrm{C}$ for $30 \mathrm{~min}$. The enzymatic reaction was stopped by adding $250 \mu \mathrm{L} 1 \mathrm{~N}$ $\mathrm{HCl}$ (except for the control) to each assay mixture. The hippuric acid formed was extracted with $1.0 \mathrm{~mL}$ ethyl acetate by vortex mixing for $15 \mathrm{~s}$. An aliquot of $0.70 \mathrm{~mL}$ of ethyl acetate layer from each mixture was collected and evaporated to dryness. The hippuric acid that remained was redissolved in $1.30 \mathrm{~mL}$ water and the absorbance of the resulting solution was read at $228 \mathrm{~nm}$. Pulverized Captopril served as positive control.

The percent inhibition of the protein hydrolysates was calculated using the equation adopted from Li et al. (2005):

$$
\begin{array}{r}
\text { ACE inhibition }(\%)=\frac{B-A}{B-C} \times 100 \\
\text { (Equation 1) }
\end{array}
$$

where $\mathrm{A}$ is the absorbance of hippuric acid generated in the presence of ACE inhibitor (sample); $\mathrm{B}$ is the absorbance of the hippuric acid generated without the ACE inhibitor (blank); and $\mathrm{C}$ is the absorbance of hippuric acid generated without ACE (control).

The $\mathrm{IC}_{50}$ value is defined as the concentration of peptide inhibitor required to inhibit $50 \%$ of the ACE activity under assayed conditions. The value was determined using GraphPad ${ }^{\circledR}$ Prism 6 software. 
Antioxidative Activity Assay. Hydroxyl Radical Scavenging Activity. The hydroxyl radical scavenging activity of the $24 \mathrm{~h}$ trypsin and chymotrypsin hydrolysates was determined according to the method of Tanzadehpanah et al. (2012) with slight modifications. A mixture of $5.0 \mathrm{mM}$ 1,10-phenantroline, $5.0 \mathrm{mM}$ $\mathrm{FeSO}_{4}$, and $15.0 \mathrm{mM}$ EDTA were mixed with $10 \mathrm{mM}$ PBS ( $\mathrm{pH}$ 6.8). Then, $150 \mu \mathrm{L}$ of protein hydrolysate $(1 \mathrm{mg} / \mathrm{mL})$ and $210 \mu \mathrm{L}$ of $0.03 \% \quad \mathrm{H}_{2} \mathrm{O}_{2}$ were added. The resulting mixture was incubated at $37^{\circ} \mathrm{C}$ for $60 \mathrm{~min}$ and the absorbance was read at $536 \mathrm{~nm}$. Ascorbic acid $(1 \mathrm{mg} / \mathrm{mL})$ was used as a positive control. The hydroxyl radical scavenging activity was calculated using the equation:

$$
\begin{aligned}
& \text { Hydroxyl Radical Scavenging Activity (\%) } \\
& \quad=\frac{A_{c}-A_{s}}{A_{c}-A_{o}} \times 100 \quad \text { (Equation 2) }
\end{aligned}
$$

where $A_{c}$ is the absorbance of the control solution in the absence of $\mathrm{H}_{2} \mathrm{O}_{2} ; \mathrm{A}_{\mathrm{s}}$ is the absorbance of the sample; $A_{o}$ is the absorbance of the blank solution using distilled water instead of sample.

\section{2,2-diphenyl-1-picryllbydrazyl (DPPH) Radical} Scavenging Activity. A modified method of Saha et al. (2008) was used to assess the antioxidant capacity of the protein hydrolysates to quench a stable DPPH radical. Two hundred fifty microliters of protein hydrolysates at different concentrations $(0-1 \mathrm{mg} / \mathrm{mL})$ was mixed with $1.10 \mathrm{~mL} 0.004 \% \mathrm{DPPH}$ solution (in $95 \%$ ethanol). The mixture was shaken vigorously using vortex mixer. The reaction mixture was incubated for $30 \mathrm{~min}$ in the dark at room temperature. The absorbance was then measured at $519 \mathrm{~nm}$. Ethanol and ascorbic acid was used as blank and positive control, respectively. The radical scavenging activity of the sample was calculated using the equation:

$$
\begin{aligned}
& \text { DPPH Radical Scavenging Activity (\%) } \\
& \quad=\frac{A_{o}-A_{s}}{A_{o}} \times 100 \quad \text { (Equation 3) }
\end{aligned}
$$

where $A_{\circ}$ is the absorbance of the blank solution using $95 \%$ ethanol instead of sample and $A_{s}$ is the absorbance of the sample.
The $\mathrm{EC}_{50}$ value is defined as an effective concentration of protein hydrolysates that is required to scavenge $50 \%$ of DPPH radical activity under assayed conditions and determined using GraphPad $^{\circledR}$ Prism 6 software.

Antimicrobial Susceptibility Assay. The antibacterial activity of the protein hydrolysates against Escherichia coli (BIOTECH 1634) and Staphylococcus aureus (BIOTECH 1582) was done by disc diffusion method. Mueller Hinton Agar (MHA) was used as the medium for the two test microbial stocks.

Molten MHA was inoculated via pour plate method with $1.0 \mathrm{~mL}$ of the $24 \mathrm{~h}$ old test microbial stocks dissolved in saline solution. The inoculated medium was then poured into a plate at around $4 \mathrm{~mm}$ in depth and was allowed to solidify at room temperature.

Filter paper discs of approximately $6 \mathrm{~mm}$ in diameter were soaked with $15 \mu \mathrm{L}$ of the protein digests and were placed in the inoculated MHA plate. Each disc was pressed down to ensure complete contact with the agar surface and distributed evenly. The agar plates were incubated for $12 \mathrm{~h}$ at $37^{\circ} \mathrm{C}$. Sterile water discs were used as negative control and $10 \%$ phenol discs as positive control. The diameter of zone of complete inhibition (in $\mathrm{mm}$ ) of the protein hydrolysates against the two microbial stocks was measured and compared with that of the diluent $(0.010 \mathrm{M}$ PBS, pH 6.8) and the controls.

Densitometric Analysis. The electrophoretograms were scanned and the resulting images were analyzed using ImageJ software (Abramoff et al., 2004) to determine the degree of hydrolysis of the proteins.

Statistical Analysis. All analyses were done in duplicates and subjected to ANOVA followed by Tukey's test at $\mathrm{p}<0.05$ level using GraphPad $^{\circledR}$ Prism 6 software. The activity for each assay is expressed as mean activity \pm standard deviation. 


\section{RESULTS AND DISCUSSION}

Extraction of the Total Soluble Proteins from Pistachio Nuts. The total soluble proteins of pistachio nuts (TSPPN) were extracted using $0.010 \mathrm{M}$ phosphate buffered saline ( $\mathrm{pH}$ 6.8). The protein content of this extract was found to be $1.23 \mathrm{mg} / \mathrm{mL}$. SDSPAGE profile of TSPPN reveals 5 major protein bands with approximate molecular weights of 56, 31, 26, 24, and $13 \mathrm{kDa}$ (Figure $1)$. This protein profile was consistent with those obtained by Noorbakhsh et al. (2011). According to Shokraii and Esen (1988), majority of the proteins from pistachio nut are globulins amounting to $66.0 \%$, followed by albumins, glutelins, and prolamins, amounting to $25.0,7.3$, and $2.0 \%$, respectively.

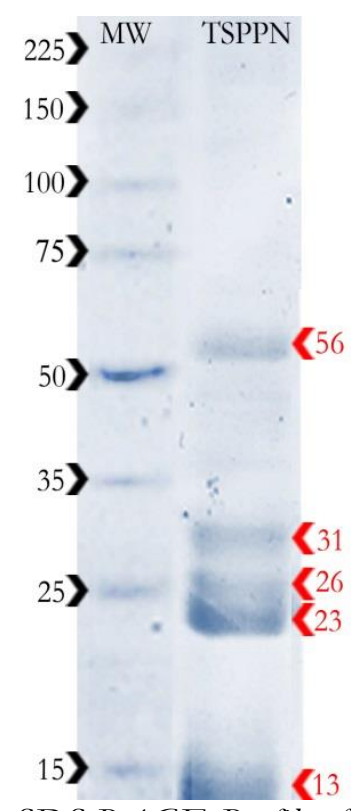

Figure 1. SDS-PAGE Profile of the Total Soluble Proteins of Pistachio Nuts (TSPPN). MW: Molecular Weight Markers; TSPPN: Total Soluble Proteins of Pistachio Nuts.

Enzymatic Hydrolysis of TSPPN. The enzymatic digestibility of TSPPN using chymotrypsin (Figure 2a) and trypsin (Figure $2 \mathrm{~b})$ were evaluated at different time intervals from $0 \mathrm{~min}$ to $24 \mathrm{~h}$ (Figure 2). It was observed that the $56 \mathrm{kDa}$ polypeptide of TSPPN was the most susceptible to digestion for both enzymes. Even at $0 \mathrm{~min}$, the short contact time between the proteins and enzyme prior to immediate boiling was enough to cleave the protein into smaller fragments. Moreover, it also possible that $56 \mathrm{kDa}$ polypeptide contains more cleavage sites for trypsin and chymotrypsin than the other polypeptides which explains the ease of its hydrolysis (Fastrez and Fersht, 1973). Using densitometric analysis, $73 \%$ and $60 \%$ of the $56 \mathrm{kDa}$ polypeptide were hydrolyzed by chymotrypsin and trypsin, respectively.

On the contrary, three polypeptides were fairly resistant to chymotrypsin and trypsin. It can be noted that chymotrypsin was able to digest completely the $31 \mathrm{kDa}$ and $26 \mathrm{kDa}$ polypeptides only after $5 \mathrm{~h}$ of incubation. However, the $23 \mathrm{kDa}$ polypeptide was fairly resistant to chymotrypsin digestion such that $60 \%$ of the polypeptide still remained after 24 $\mathrm{h}$ of digestion.

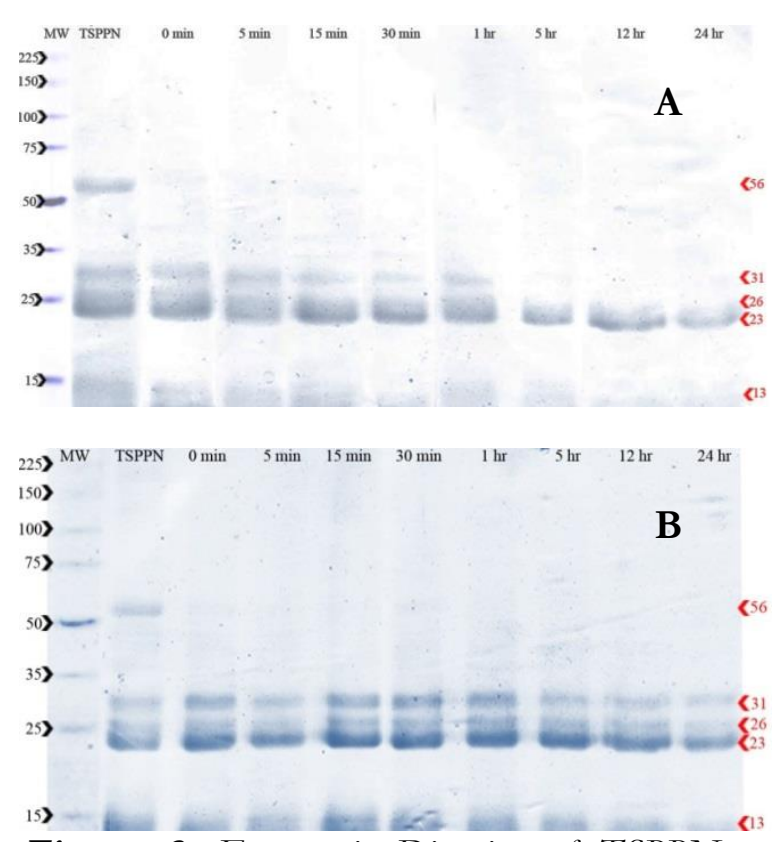

Figure 2. Ensymatic Digestion of TSPPN at Different Time Intervals using (A) Chymotrypsin and (B) Trypsin. Lane MW: Molecular Weight Markers; TSPPN: Total Soluble Proteins of Pistachio Nuts.

In general, TSPPN showed more resistance to digestion using trypsin. After $24 \mathrm{~h}$ digestion, 75,76 and $90 \%$ remained for the 31, 26, and $23 \mathrm{kDa}$ polypeptides, respectively. The differences in the susceptibility of the polypeptides to enzymatic hydrolysis may be attributed to differences in amino acid content and sequences. Likewise these three polypeptides may contain greater number of cleavage sites for chymotrypsin than trypsin. 
Angiotensin-Converting Enzyme (ACE) Inhibition Assay. Preliminary ACE inhibition assay shows that both tryptic and chymotryptic hydrolysates yielded ACE inhibition activities at different digestion times as shown in Figure 3. However, the highest ACE inhibition activity of $76.67 \%$ and $70.83 \%$ was observed at $24 \mathrm{~h}$ for chymotrypsin and trypsin, respectively. Although no significant differences in terms of ACE inhibition activity were obtained at different time intervals for chymotryptic digestion, still the $24 \mathrm{~h}$ digestion time was chosen for RP-HPLC fractionation due to the extent of hydrolysis whereby the concentration of smaller peptides was expected to be the highest. According to Hernandez-Ledesma et al. (2011), majority of the ACE inhibitory peptides have relatively short sequences, ranging from 2 to 12 amino acids, since the inhibition site for ACE cannot accommodate much larger peptide molecules. Hyun and Shin (2000) also observed that ACE inhibitory peptides are effectively released after $24 \mathrm{~h}$ of digestion or when the hydrolysis of the protein is almost complete.

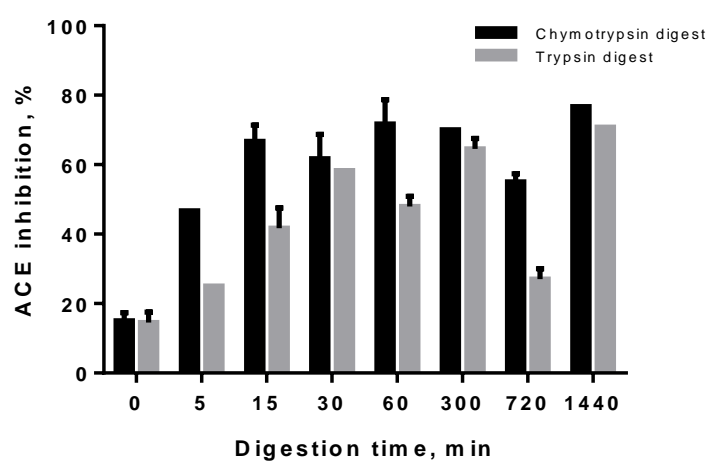

Figure 3. Percent ACE inbibition of chymotryptic and tryptic bydrolysates of TSPPN digested at different time intervals $(60 \mathrm{~min}=1 \mathrm{~b} ; 300 \mathrm{~min}=5$ b; 720 min $=12$ b; $1440 \mathrm{~min}=24$ b).

Fractionation of $24 \mathrm{~h}$ Chymotryptic and Tryptic Hydrolysates using RP-HPLC. Figure 4 shows the RP-HPLC profile of the $24 \mathrm{~h}$ chymotryptic (Figure $4 \mathrm{a}$ ) and tryptic (Figure 4b) hydrolysates. Both profiles shows several peaks but only three peaks were chosen for ACE assay for the chymotryptic hydrolysates (labelled C1, C2, and C3) while two were selected for the tryptic hydrolysates (labelled T1 and T2). Table 1 shows the ACE inhibitory activities of the selected peaks and their corresponding $\mathrm{IC}_{50}$ values.
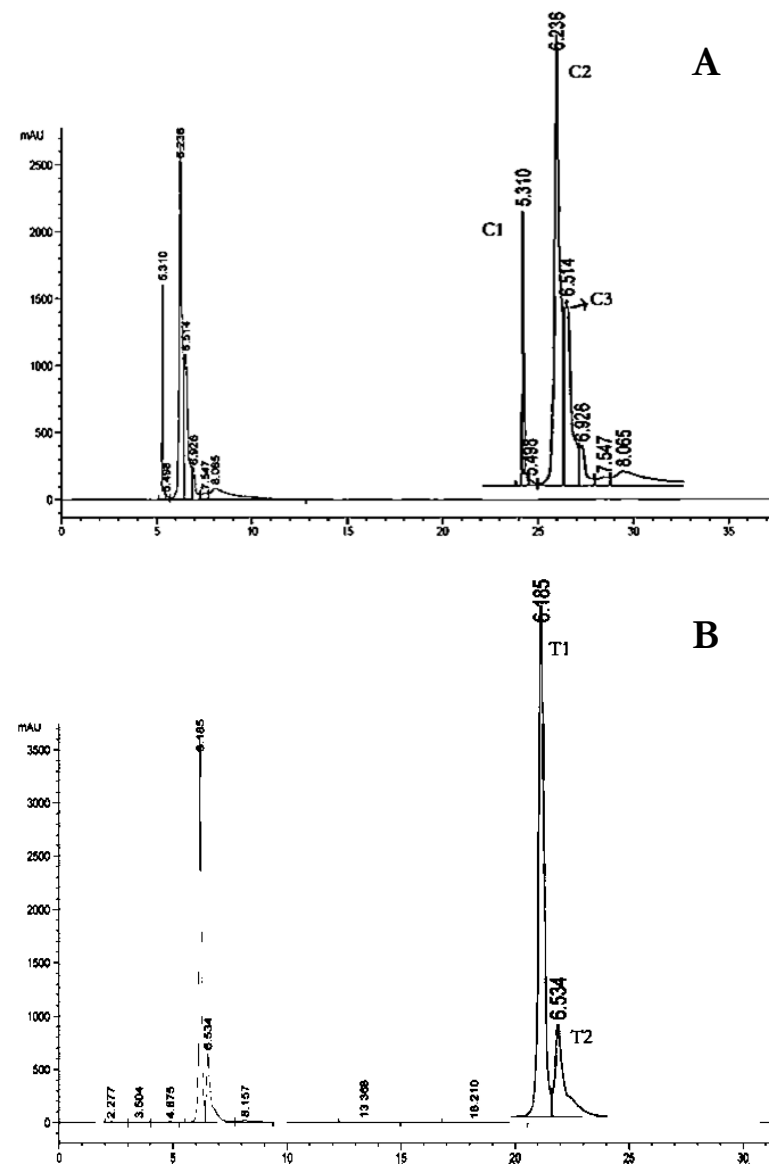

Figure 4. RP-HPLC profiles of the $24 h(A)$ chymotryptic (B) tryptic bydrolysates. Inset: magnified chromatograms.

Table 1. ACE Inhibition Activities of the 24 h Hydrolysates from RP-HPLC Fractionation.

\begin{tabular}{lll}
\hline $\begin{array}{l}\text { Fraction } \\
\text { No. }\end{array}$ & $\begin{array}{l}\text { ACE } \\
\text { inhibition }(\%)\end{array}$ & $\begin{array}{l}\mathbf{I C}_{50} \\
(\boldsymbol{\mu g} / \mathbf{m L})\end{array}$ \\
\hline $\mathrm{C} 1$ & $65.04 \pm 4.38$ & $147.7 \pm 0.8$ \\
\hline $\mathrm{C} 2$ & $27.88 \pm 1.19$ & nd \\
\hline $\mathrm{C} 3$ & $23.01 \pm 0.00$ & nd \\
\hline $\mathrm{T} 1$ & $58.41 \pm 1.25$ & $236.4 \pm 3.0$ \\
\hline $\mathrm{T} 2$ & $71.24 \pm 6.88$ & $148.7 \pm 0.6$ \\
\hline $\begin{array}{l}\text { Captopril } \\
\text { (positive } \\
\text { control) }\end{array}$ & $94.53 \pm 2.21$ & $67.01 \pm 2.21$ \\
\hline *nd: & & \\
\hline
\end{tabular}

*nd: not determined 
It can be noted that from among the chymotryptic hydrolysates, C1 exhibited the highest ACE inhibition activity of 65.04\% while $\mathrm{C} 3$ has the lowest activity with a value of $23.01 \%$. On the other hand, for the tryptic hydrolysates, T2 showed a relatively higher activity than $\mathrm{T} 1$, with a value of $71.24 \%$. However, the individual inhibitory activity of the fractions does not surpass that of captopril, a known ACE inhibitor and a prescribed medicine for hypertension. But, the synergistic activities of all these peptide fractions may ultimately have an impact in controlling and alleviating hypertension.

\section{Hydroxyl and DPPH Radical Scavenging} Assays of the 24 h Hydrolysates. The $24 \mathrm{~h}$ chymotryptic and tryptic hydrolysates, which have the highest degree of protein hydrolysis, were also screened for any antioxidant activity. As shown in Table 2, both tryptic and chymotryptic hydrolysates contained peptides that were able to scavenge the generated hydroxyl radical. Between the two, the chymotryptic hydrolysates have consistently exhibited a greater antioxidant effect of $22.802 \%$ and $\mathrm{EC}_{50} 356.451$, for hydroxyl and $\mathrm{DPPH}$ radical scavenging activities, respectively. On the other hand, the tryptic hydrolysates exhibited a lower antioxidant ability of $16.616 \%$ and $\mathrm{EC}_{50} 402.717$ for hydroxyl and DPPH radical scavenging activities, respectively. However, when compared with ascorbic acid which is a known natural antioxidant, the radical scavenging activities of both hydrolysates were significantly lower and were less effective. In a similar study by Amsa et al. (2013), they noted that the radical scavenging activity was strongly correlated to the degree of hydrolysis polypeptide. Hence, the use of other proteolytic enzymes or longer digestion time may be necessary to hydrolyze the remaining undigested polypeptides and release more effective antioxidants. Abu-Salem et al. (2013) also reported that low molecular peptides generally exhibit higher antioxidant properties. Hydrolysis of proteins is also favored in generating and releasing potent antioxidant peptides (Bamdad et al., 2011; Chanput et al., 2009). Other studies also indicate that peptides released from protease digestion of nut proteins, such as peanut and walnut, have potent DPPH and hydroxyl radical scavenging activities (Chen et al. 2012; Ji et al. 2014).

Table 2. Antioxidant activities of the $24 \mathrm{~h}$ chymotryptic and tryptic hydrolysates.

\begin{tabular}{lcc}
\hline Sample & $\begin{array}{c}\text { Hydroxyl Radical } \\
\text { Scavenging Activity } \mathbf{( \% )}\end{array}$ & $\begin{array}{c}\text { DPPH Radical Scavenging } \\
\text { Activity, } \mathbf{E C}_{\mathbf{5 0}}(\boldsymbol{\mu g} / \mathbf{m L})\end{array}$ \\
\hline Chymotryptic Hydrolysates & $22.802 \pm 1.029$ & $356.451 \pm 1.047$ \\
\hline Tryptic Hydrolysates & $16.616 \pm 3.688$ & $402.717 \pm 1.065$ \\
\hline Positive Control (Ascorbic acid) & $97.968 \pm 0.129$ & $125.893 \pm 1.050$ \\
\hline
\end{tabular}

\subsection{Antimicrobial Susceptibility Assay}

The presence of antimicrobial peptides in the $24 \mathrm{~h}$ chymotryptic and tryptic hydrolysates were also determined using disc diffusion method. As shown in Figure 5, there were no zones of inhibition observed for both $24 \mathrm{~h}$ hydrolysates against the gram-positive Staphylococcus aureus (Figure 5a) and gramnegative Escherichia coli (Figure 5b). The results imply that the hydrolysates were devoid of biocidal peptides generated by the cleavage specificities of chymotrypsin and trypsin. It is also possible that peptides released upon hydrolysis with these proteases do not conform to an overall secondary structure with biocidal activity since there is a strong correlation between peptide structure and function of antimicrobial peptides (Epand and Vogel, 1999). The use of other proteolytic enzymes or a combination of such may produce peptides with antimicrobial and antiviral activities (Florisa et al., 2003; Pellegrini, 2003; Zeng et al., 2008). 


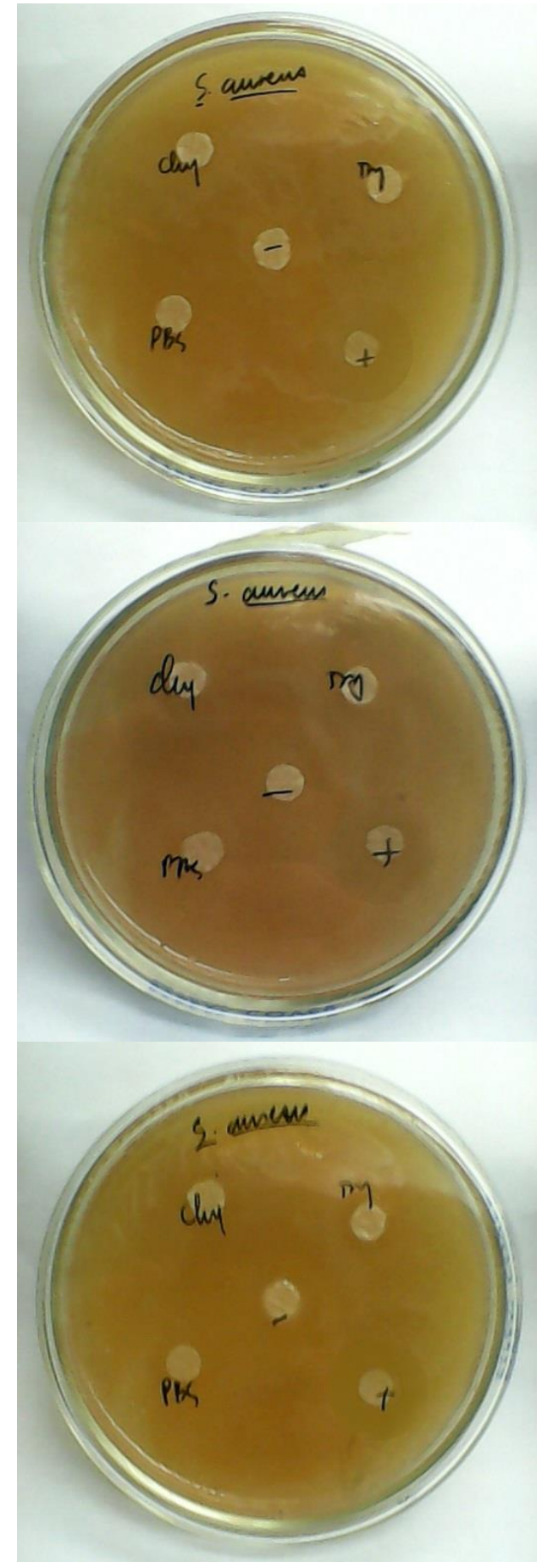

A

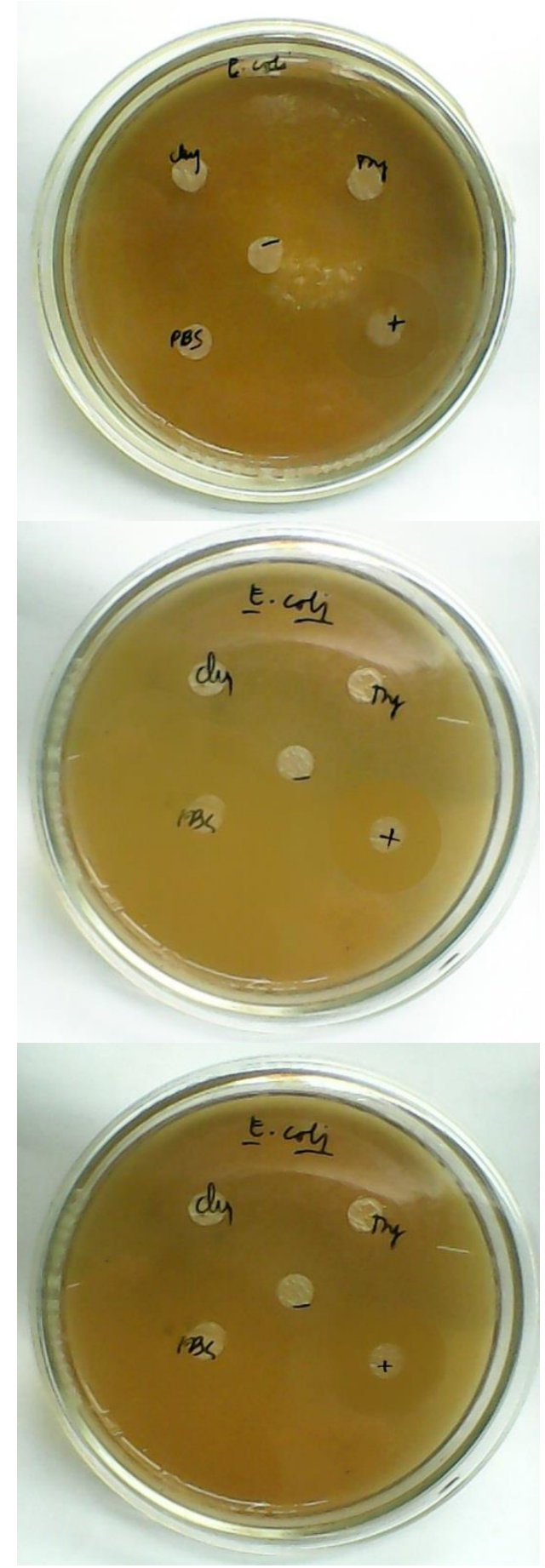

B

Figure 5. Antimicrobial susceptibility assay of the $24 \mathrm{~b}$ bydrolysates against (a) Staphylococcus aureus and (b) Escherichia coli. (Chy: 24 h chymotryptic bydrolysate; Try: 24 b tryptic hydrolysate; PBS: diluent control; (-): negative control; (+): positive control).

\section{CONCLUSION}

The total soluble proteins of pistachio nuts were found to contain bioactive peptides exhibiting ACE inhibition and antioxidant activities. These peptides were released from their parent proteins through enzymatic hydrolysis using chymotrypsin and trypsin. The $24 \mathrm{~h}$ chymotryptic and tryptic hydrolysates showed the highest ACE inhibition activities and the same hydrolysates also displayed hydroxyl and DPPH radical 
scavenging activities. However, the $24 \mathrm{~h}$ hydrolysates from both enzymes were devoid of antimicrobial activities against the gramnegative Escherichia coli and gram-positive Staphylococcus aureus.

\section{ACKNOWLEDGEMENT}

The authors would like to thank the Institute of Chemistry, College of Arts and Sciences, UPLB for the financial support of this project.

\section{REFERENCES}

Abramoff MD, Magalhães PJ, Ram SJ. Image processing with ImageJ. Biophotonics International. 2004; 11(7):36-42.

Abu-Salem FM, Mahmoud MH, Gibriel AY, Abou-Arab A. Characterization of antioxidant peptides of soybean protein hydrolysate. World Acad. Sci. Eng. Technol. 2013; 79:249-253.

Amsa T, Balla A, Tounkara F, Man L, Zhou HM. Effect of hydrolysis time on nutritional, functional and antioxidant properties of protein hydrolysates prepared from gingerbread plum (Neocarya macrophylla) seeds. Int. Food Res. J. 2013; 20(5):2081-2090.

Bamdad F, Wu J, Chen L. Effects of enzymatic hydrolysis on molecular structure and antioxidant activity of barley hordein. J. Cereal Sci. 2011 Jul; 54(1):20-28.

Bowler R, Crapo J. Oxidative stress in allergic respiratory diseases. J. Allergy Clin. Immunol. 2002; 110(3):349-356.

Bradford MM. A rapid and sensitive method for the quantitation of microgram quantities of protein utilizing the principle of proteindye binding. Anal. Biochem. 1976 May 7; $72: 248-254$.

Brogden N, Brogden K. Will new generations of modified antimicrobial peptides improve their potential as pharmaceuticals? Int. J. Antimicrob. Ag. 2011; 38:217-225.

Chanput W, Theerakulkait C, Nakai S. Antioxidative properties of partially purified barley hordein, rice bran protein fractions and their hydrolysates. J. Cereal Sci. 2009 May; 49(3):422-428.

Chen N, Yang $H$, Sun Y, Niu J, Liu S. Purification and identification of antioxidant peptides from walnut (Juglans regea L.) protein hydrolysates. Peptides. 2012 Dec; 38(2):344-349.

Cheung H-S, Wang F-L, Ondetti MA, Sabo EF, Cushman DW. Binding of peptide substrates and inhibitors of angiotensinconverting enzyme. J. Biol. Chem. 1980; 255(2):401-407.

Cushman DW, Cheung HS. Spectrophotometric assay and properties of the angiotensin-converting enzyme of rabbit lung. Biochem. Pharmacol. 1971 Jul; 20(7):1637-1648.

Dhalla N, Temsah R, Netticadan T. Role of oxidative stress in cardiovascular diseases. J. Hypertens. 2000 Jun; 18(6):655-673.

Elias RJ, Kellerby SS, Decker E. Antioxidant activity of proteins and peptides. Crit. Rev. Food Sci. Nutr. 2008; 48:430-441.

Epand RM, Vogel HJ. 1999. Diversity of antimicrobial peptides and their mechanisms of action. Biochim. Biophys. Acta. 1999; 1462:11-28.

Fastrez J, Fersht AR. Demonstration of the acyl-enzyme mechanism for the hydrolysis of peptides and anilides by chymotrypsin. Biochemistry.1973 May; 12(11):2025-2034.

Florisa R, Recio I, Berkhout B, Visser S. Antibacterial and antiviral effects of milk proteins and derivatives thereof. Curr. Pharm. Des. 2003 Jan; 9(16):1257-1275.

Folk JE, Piez KA, Carroll WR, Gladner JA. Carboxypeptidase B: IV. purification and characterization of the porcine enzyme. J. Biol. Chem. 1960; 235(8):2272-2277.

Halvorsen B, Carlsen M, Phillips K, Bohn S, Holte Jr. K, Jacobs D. Content of redox- 
active compounds (i.e. antioxidants) in food consumed in the United States. Am. J. Clin. Nutr. 2006; 84:95-135.

Hernández-Ledesma B, del Mar Contreras M, Recio I. Antihypertensive peptides: production, bioavailability and incorporation into foods. Adv. Colloid Interface Sci. 2011 Jun 9; 165(1):23-35.

Hyun C-K, Shin H-K. Utilization of bovine blood plasma proteins for the production of angiotensin I converting enzyme inhibitory peptides. Process Biochem. 2000 Sep; 36(12):65-71.

Ji N, Sun C, Zhao Y, Xiong L, Sun Q. Purification and identification of antioxidant peptides from peanut protien hydrolysates using UHR-Q-TOF mass spectrometer. Food Chem. 2014 Oct; 161:148-154.

Korhonen H, Pihlanto A. Bioactive peptides: production and functionality. Int. Dairy J. 2006; 16:945-960.

Li G-H, Liu H, Shi Y-H, Le G-W. Direct spectrophotometric measurement of angiotensin I-converting enzyme inhibitory activity for screening bioactive peptides. J. Pharm. Biomed. Anal. 2005 Feb 23; 37(2):219-224.

Natesh R, Schwager SLU, Sturrock ED, Acharya KR. Crystal structure of the human angiotensin-converting enzyme-lisinopril complex. Nature. 2003; 421:1427-1429.

National Statistics Office, Civil Registry Department, Vital Statistics Division. Deaths: Philippines 2009. Report No. 2012-719 [Internet]. 2013 October; Available from: http://www.census.gov.ph/ old/data/sectordata/ sr12719tx.html

Noorbakhsh R, Mortazavi SA, Sankian M, Shahidi F, Tehrani M, Azad FJ, et al. Pistachio allergy-prevalence and in vitro cross-reactivity with other nuts. Allergol. Int. 2011; 60:425-432.

Orhan I, Kupeli E, Aslan M, Kartal M, Yesilada E. Bioassay-guided evaluation of anti-inflammatory and antinociceptive activities of pistachio, Pistacia vera L. J. Ethnopharmacol. 2006 Apr; 105(1-2):235-240.

Ozcelik B, Aslan M, Orhan I, Karaoglu T. Antibacterial, antifungal, and antiviral activities of the lipophylic extracts of Pistacia vera. 2005; 160:159-164.

Park H, Kim S, Lee Y. Impact of oxidative stress on lung diseases. Respirology. 2009; 14(1):27-38.

Pellegrini A. Antimicrobial peptides from food proteins. Curr. Pharm. Des. 2003 Jan; 9(16):1225-1238.

Rajaei A, Barzegar M, Mobarez A, Sahari M, Esfahani Z. Antioxidant, anti-microbial and antimutagenicity activities of pistachio (Pistacia vera) green hull extract. Food Chem. Toxicol. 2010 Jan; 48(1):107-112.

Ros E. Health benefits of nut consumption. Nutrients. 2010; 2:652-682.

Saha MR, Hasan SMR, Akter R, Hossain MM, Alam MS, Alam MA, et al. In vitro free radical scavenging activity of methanol extract of the leaves of Mimusops elengi Linn. Bangl. J. Vet. Med. 2008; 6(2):197-202.

Shokraii EH, Esen A. Composition, solubility and electrophoretic patterns of proteins isolated from Kerman pistachio nuts (Pistacia vera L.). J. Agric. Food Chem. 1988 May; 36(3):425-429.

Tanzadehpanah H, Asoodeh A, Chamani J. An antioxidant peptide derived from Ostrich (Struthio camelus) egg white protein hydrolysates. Food Res. Inter. 2012; 49(1):105-111.

Unger $\mathrm{T}$. The role of the renin-angiotensin system in the development of cardiovascular disease. Am. J. Cardiol. 2002; 89:3A-10A.

Zeng M, Cui W, Zhao Y, Liu Z, Dong S, Guo $Y$. Antiviral active peptide from oyster. Chinese J. Oceanol. Limnol. 2008 Aug 20; 26(3):307-312 